\title{
INTERNATIONAL COMPETITIVENESS OF CZECH \\ MANUFACTURING - A SECTORAL APPROACH WITH ERROR \\ CORRECTION MODEL
}

\section{Magdalena Olczyk, Aleksandra Kordalska*}

\begin{abstract}
The main objective of this paper is to find the determinants of the international competitiveness of the manufacturing sectors of the Czech economy, using the database of 13 manufacturing subsectors in 1995-2011, with the aid of ECM model. The authors research the question of how much foreign and domestic demand, the level of labour costs, the level of sector innovation intensity, the level of sector openness to foreign markets as well as sectoral labour productivity influence the changes in their trade balance. The results of the analysis conducted show substantial differences in the roles particular variables play in explaining the net exports in individual sectors. The results of the analysis indicate mostly a greater impact of the researched factors on net exports in long rather than short term.
\end{abstract}

Keywords: net exports, international competitiveness of economy, CEE economies, manufacturing, error correction model

JEL Classification: F40, C23, F14, O14, L60

\section{Introduction}

The Czech Republic is the leading economy among Central and East-European countries, with $88 \%$ share of manufacturing goods in total exports and with the 20th highest place in the ranking of the most industrialized economies. In addition, the Czech economy has been characterized by positive net exports in the manufacturing sector since 2002, in contrast to other CEE countries, e.g. Poland, which has achieved a positive balance in manufacturing trade since 2009.

From this, the international competitiveness of the Czech Republic and other CEE countries can be analysed in terms of their results in manufacturing trade, especially in terms of the achieved trade balance in manufacturing sector. In literature a trade balance is treated by some authors as a good indication and measure of narrowly defined international economic competitiveness (Deardorff, 1980; Greenhalgh et al., 1994; Soete, 1981).

The research identifying the determinants of manufacturing foreign trade balance of Central and East-European countries is scarce. The one which can be found is based on highly aggregated data and focuses on one chosen determinant. For this reason the authors relying on disaggregated data for 13 manufacturing sub-sectors and using a dynamic ECM model aim to specify the determinants of international competitiveness of manufacturing sector in 1995-2011 for Czech economy. The study has been conducted simultaneously in two ways. In the first place a panel model for Czech manufacturing based on a yearly

* Magdalena Olczyk, Gdansk University of Technology, Faculty of Management and Economics, Gdansk, Poland (Magdalena.Olczyk@zie.pg.gda.pl);

Aleksandra Kordalska. Gdansk University of Technology, Faculty of Management and Economics, Gdansk, Poland (Aleksandra.Kordalska@zie.pg.gda.pl); 
data from 13 manufacturing sectors in 1995-2011 has been estimated (the so called "shared model"). Then sector level panel models allowing individual identification of both short and long-term relations between net exports and some of its determinants have been estimated.

The structure of the article is as follows. In the first part theoretical foundations of the relationship between the volume of foreign trade balance and its determinants have been presented. Next both data and the methodology of the conducted research have been shown. In the subsequent part the authors present the results of the empirical analysis of the influence of chosen factors on trade balance in manufacturing in the Czech Republic in 1995-2011. The last part of the article contains conclusions drawn from the conducted research.

\section{Related Literature on Net Export Determinants}

Domestic and foreign demands are main determinants of net exports. About the relationship between demand and trade balance we can find in literature in elastic approach to balance of payments by Robinson (Robinson, 1937), in a Porter's model of diamond (1990) or in a Dixit-Stiglitz's model "love of diversity" (Dixit, Stiglitz, 1977).

The authors' hypothesis is that a high level of domestic demand does not help improve international competitiveness of manufacturing sectors measured by foreign trade balance since it has a negative effect on the pace of exports growth and a positive effect on imports dynamics. Due to partial substitutability between sales on domestic and foreign markets, entrepreneurs want to compensate for the decrease of demand on the domestic market by selling abroad, and if the economic situation in their country is good, they concentrate on the domestic market, which is easier and they know it better. A negative relationship between the level of domestic demand and exports can be found in works of Faini (1994), Sharma (2003). The relationship between exports and domestic demand can be positive. This can be due to the fact that some export-entrepreneurs do not limit their exports in times of high domestic demand on account of substantial prior investments they made to enter foreign markets.

The authors' hypothesis is that a high level of foreign demand fosters international competitiveness of the manufacturing sector measured by the foreign trade balance. This hypothesis is based on a model of imperfect substitutes related to trade balance (trade balance approach), put forward by Bahmani-Oskooee (1985). Trade balance is then a function of foreign demand, domestic production capacity, the size of monetary base both domestic and foreign and real effective exchange rates deflated with domestic wholesale prices. In Bahmani-Oskooee's (1985) analysis of quarterly data in 1973-1980 in Greece, India, Korea and Thailand, the estimated influence of foreign demand on trade balance was positive. Additionally, Bahmani-Oskooee (1991) proposed substituting of traditionally understood trade balance (the difference between exports and imports) with export-import quotient, which is also an approach taken by the authors in this paper.

Price is an equally important determinant of international competitiveness. According to literature overview by Turner and Van't dack (1993) and literature analysis by Turner and Golub (1997), in industrialized economies relative unit labour costs (RULC) in industry seem to be the best singular measure of cost/price competitiveness. There are few studies in which the influence of relative labour cost on trade balance is analysed, the relationship between these variables is sometimes positive and sometimes negative. In Lewney's studies of manufacturing sector in 15 EU countries in 1998-2008 the decrease of RULC fostered the generation of positive trade balance in 10 countries, in 3 countries it negatively influenced this balance and in the remaining two RULC remained a statistically unimportant variable (Lewney, 2011). 
The level of innovation is yet another determinant of international competitiveness of a country/sector. In foreign trade theories the influence of R\&D investments on trade intensity is underlined. In particular in the technological gap theory by Posner (1961), in the life-cycle theory by Vernon (1966) and in the later Krugman's analyses (1979; Dollar, 1986) it is indicated that innovation is a potential source of competitive advantage and an incentive to export intensification. In competitiveness models some economists posit a positive relationship between innovation and largely defined competitiveness of economy/ sector (Porter, 1990). On the other hand, Thirlwall (1988) in his demand model showed yet a different channel of innovation transmission which influenced the growth of economy's competitiveness. It turns out countries offering products characterized by narrow variety and low quality face a problem with the demand curve of imported goods, the curve which has high elasticity of income. For this reason quite often these countries generate a negative trade balance. It is through innovation that they can improve the quality as well as broaden the assortment of exported goods. Consequently they can also achieve a positive trade balance, which can be a sign of their competitiveness growth.

There is a lot of empirical literature in which the positive influence of innovation on trade balance in manufacturing is discussed (Greenhalgh et al., 1994; Wakelin, 1998; Anderton, 1999). In the light of the above the authors suspect that innovative sectors are net exporters rather than net importers and posit a claim (to be verified) that there is a positive relationship between innovation level and foreign trade balance in manufacturing sub-sectors.

Another factor which influences the competitiveness of manufacturing sector measured by foreign trade balance is the level of openness of a given sector, understood as the share of trade balance in gross domestic product. In endogenous growth theories on macro and mezzo scale (Rivera-Batiz, Romer, 1991; Grossman, Helpman, 1991) attention is paid to long-term advantages from trade openness like a quicker technological transmission, the increase of specialization (via learning by doing) or the relocation of economic factors to more productive sectors, which have a comparative edge in trade (Melitz, 2003).

In empirical analyses on sector level Cameron et al. (2005) pointed out a statistically viable influence of trade openness on the intensity of technological transfer in 14 British manufacturing sub-sectors. According to Sun et al. (1999) who analysed 28 industrial subsectors in 29 Chinese provinces in 1995, trade openness has a positive effect on sectors' technical efficiency growth, which is due to benefiting from effect of the economy of scale and better absorption of technology. In the light of the above the authors posit a hypothesis that the openness of manufacturing sector fosters competitiveness measured by trade balance.

Labour productivity is another factor whose power and direction as well as influence on the competitiveness of trade balance the authors aim to verify. Theoretical relationships between productivity and trade balance are to be found in the latest trends of foreign trade theories. In new trade theory (New, New Trade Theory - NNTT), which is based on Melitz model (2003) and Melitz and Ottawiano model (2008), only companies with highest productivity are capable of entering and competing on export markets (self-selection hypothesis), and their activity on foreign markets leads to their expansion.

Empirical verification of a positive influence of labour productivity on export activity (higher productivity increases the probability a company enters a foreign market) based on Melitz model can be found in works of Wagner (2008), De Loecker (2007), Bustos's analysis (2011) and in works of Cieślik et al. (2012).

On the sum, the authors aim to analyse to which extent the size of foreign demand, the size of domestic demand, the level of relative unit labour costs, the level of innovation 
intensity in a sector, the level of sector openness to foreign markets and labour productivity in a sector influence the changes of international competitiveness of Czech manufacturing sectors measured by foreign trade balance.

\section{Data and Methodology}

The data on export competitiveness are taken from the WIOD database ${ }^{1}$ and the STAN OECD database. We divide the whole manufacturing sector into subsectors according to NACE 1.1. Due to lack of available data for all 14 subsectors, we combine subsector DB (manufacture of textiles and textile products) and subsector DC (manufacture of leather and leather products). Finally, we examine 13 manufacturing subsectors using balanced panel data for the period 1995-2011. The details of the dataset which we use in the analysis are presented in Table 1.

Table 1 | Details of the Dataset

\begin{tabular}{|c|c|c|}
\hline $\begin{array}{l}\text { Variable } \\
\text { Name }\end{array}$ & $\begin{array}{l}\text { Variable Description } \\
\text { (million USD) }\end{array}$ & Source of the Data \\
\hline L NEX & logarithm of ratio of export goods value to import goods value & STAN OECD \\
\hline$L F D$ & $\begin{array}{l}\text { logarithm of unweighted sum of the final consumption expenditure } \\
\text { of households, non-profit organizations serving households and } \\
\text { government, fixed capital formation and changes in inventories and } \\
\text { valuables from } 39 \text { countries }\end{array}$ & $\begin{array}{l}\text { WIOD National } \\
\text { Input-Output } \\
\text { Tables }\end{array}$ \\
\hline$L D D$ & $\begin{array}{l}\text { logarithm of sum of the final consumption expenditure of house- } \\
\text { holds, non-profit organizations serving households and government, } \\
\text { fixed capital formation and changes in inventories and valuables }\end{array}$ & $\begin{array}{l}\text { WIOD National } \\
\text { Input-Output } \\
\text { Tables }\end{array}$ \\
\hline$L R U L C$ & $\begin{array}{l}\text { logarithm of ratio of national unit labour cost to unit labour cost } \\
\text { in Germany - unit labour cost is the ratio of the sum of wages and } \\
\text { salaries to gross value added }\end{array}$ & $\begin{array}{l}\text { WIOD - Socio } \\
\text { Economic Accounts }\end{array}$ \\
\hline LOPEN & logarithm of ratio of export goods value to gross value added & $\begin{array}{l}\text { STAN OECD, WIOD } \\
\text { National Input- } \\
\text { Output Tables }\end{array}$ \\
\hline L INNO & logarithm of R\&D expenditure & $\begin{array}{l}\text { STAN OECD - R\&D } \\
\text { Expenditures in } \\
\text { Industry }\end{array}$ \\
\hline L LPRO & logarithm of ratio of production to total hours worked & $\begin{array}{l}\text { WIOD National } \\
\text { Input-Output } \\
\text { Tables, Socio- } \\
\text { Economic Accounts }\end{array}$ \\
\hline
\end{tabular}

Notes: to calculate $L F D$ date from 39 following countries are taken: Australia, Austria, Belgium, Brazil, Bulgaria, Canada, China, Cyprus, Denmark, Estonia, Finland, France, Germany, Greece, Hungary, India, Indonesia, Ireland, Italy, Japan, Korea, Latvia, Lithuania, Luxembourg, Malta, Mexico, the Netherlands, Poland, Portugal, Romania, Russia, Slovakia, Slovenia, Spain, Sweden, Taiwan, Turkey, the United Kingdom and the United States.

Source: Own elaboration.

1 At the moment, to the best of our knowledge this is the most comprehensive database available for sectoral analysis. 
Before evaluating the international competitiveness of the manufacturing sector, we assess the stationarity of the variables used in the analysis and the cointegration between the measure of competitiveness and its determinants. To evaluate the stationarity of panel data we employ three panel unit root tests: first generation tests - the Breitung test (Breitung, 2000) and the Im-Pesaran-Shin test (Im et al., 2003) - which are based on the assumption of sectional independency; and the second generation test proposed by Pesaran (2003), which allows for cross-sectional correlation. Monte Carlo experiments (Breitung, 2000; Pesaran, 2003) show that for relatively small panels all these tests perform well, both in terms of power and size.

When the non-stationarity of the variables used in the investigation is confirmed, then the cointegration procedure can be applied to test for a long-run relationship between the exports to imports ratio and its determinants. We use the Engle-Granger (1987) procedure, which focuses on testing the stationarity of the residuals obtained from a regression based on the growth-stationary variables. To assess panel cointegration, two Pedroni test statistics panel-t statistic and group-t statistic (Pedroni, 1999) - and the Kao test (Kao, 1999) are used. Comparison of the panel cointegration tests shows that these tests have sufficient power even in the case of a small sample (Kao, 1999; Örsal, 2008; Wagner and Hlouskova, 2010).

In the light of current research on estimators which are appropriate for non-stationary panel data and in the context of our sample size, cointegration vector parameters are obtained with a dynamic OLS (DOLS) estimator (Kao and Chiang, 2000). The DOLS regression uses the lag and lead values of $\Delta x_{i t}$ as additional regressors of $y$ and is expressed as follows:

$$
y_{i t}=\alpha_{i}+x_{i t}^{\prime} \beta+\sum_{j=-q}^{q} c_{i j} \Delta x_{i, t+j}+v_{i t} .
$$

From the point of view of this analysis, SUR estimation seems to be an interesting approach. It allows heterogeneous coefficients for each subsector to be obtained. In the case of non-stationary data, Mark et al. (2005) propose a DSUR estimator. Its construction is similar to the DOLS estimator with endogeneity controlled by introducing the lags and leads of $\Delta x_{i t}$ which come from the whole system. Assuming that:

$$
z_{q i t}^{\prime}=\left(\Delta x_{i, t-q}^{\prime}, \ldots, \Delta x_{i, t+q}^{\prime}\right), \quad z_{q t}^{\prime}=\left(z_{q 1 t}^{\prime}, \ldots, z_{q N t}^{\prime}\right),
$$

where $q$ is the number of lags / leads, the DSUR regression looks as follows:

$$
y_{i t}=x_{i t}^{\prime} \beta_{i}+z_{q t}^{\prime} \delta_{q i}+v_{i t}
$$

\section{Empirical Results}

According to the methodology described in the previous section, our empirical analysis of the determinants of manufacturing sector competitiveness begins with assessment of the panel unit root. We use three tests: the Breitung test, the IPS test and the CADF Pesaran test. The results are reported in Table 2.

Evaluation of the panel unit root indicates that in the overwhelming majority of cases (logarithms of $N E X, D D, F D, F D D D, O P E N, I N N O$ ) we can clearly consider that they are stationary in first differences. However, due to a low p-value in the IPS test for the logarithms of $R U L C$ and $L P R O$ we also compute another first generation tests - Fisher type tests which do not allow rejecting the null. Finally, we can treat all the variables as integrated in first order. 
Table 2 | Results for Panel Unit Root Tests

\begin{tabular}{|c|c|c|c|c|c|c|c|}
\hline Variable & Breitung & IPS & CADF & Variable & Breitung & IPS & CADF \\
\hline L NEX & -0.580 & -1.247 & 0.303 & $\triangle L N E X$ & $-2.637^{* * *}$ & $-13.49 * * *$ & $-2.210^{* *}$ \\
\hline$L D D$ & -0.320 & 0.088 & 0.655 & $\Delta L D D$ & $-3.223^{* * *}$ & $-3.107^{* * *}$ & $-2.783^{* * *}$ \\
\hline$L F D$ & 1.495 & -1.136 & 0.656 & $\Delta L F D$ & $-3.571^{* * *}$ & $-4.270^{* * *}$ & $-2.503^{* * *}$ \\
\hline$\angle F D D D$ & -0.486 & -0.023 & 2.034 & $\triangle L F D D D$ & $-3.093 * * *$ & $-7.400^{* * *}$ & $-2.240^{* * *}$ \\
\hline$L R U L C$ & -0.287 & $-1.791^{* *}$ & 0.732 & $\Delta L R U L C$ & $-4.741^{* * *}$ & $-6.279 * * *$ & $-4.386^{* * *}$ \\
\hline L OPEN & -0.685 & -1.22 & 0.146 & $\triangle L$ OPEN & $-3.611^{* * *}$ & $-12.62^{* * *}$ & $-2.651^{* * *}$ \\
\hline L INNO & -0.722 & -1.271 & 0.941 & $\Delta L I N N O$ & $-9.346^{* * *}$ & $-9.510 * * *$ & $-1.942^{* *}$ \\
\hline L LPRO & -1.081 & $-1.469^{*}$ & 14.35 & $\Delta L L P R O$ & $-3.168^{* * *}$ & $-7.714^{* * *}$ & $-4.603^{* * *}$ \\
\hline
\end{tabular}

Notes: ${ }^{*}$ significant at the 0.1 level, ${ }^{* *}$ significant at the 0.05 level, ${ }^{* *}$ significant at the 0.01 level; for the Breitung and IPS tests the maximum lag is selected automatically in Eviews; the automatic lag length selection is based on the SIC criterion; the regressions for all the variables and for the first differences of $L F D, L R U L C$ and $L I N N O$ contain individual effects and the individual linear trend; for the first differences of the remaining variables the regressions contain individual effects only.

Source: Own calculation.

The next step is devoted to cointegration analysis. Regressions (4) and (5) contain non-stationary variables only. The first model ( $L N E X^{C Z}-$ Model 1$)$ takes the logarithm of domestic demand and the logarithm of foreign demand separately into account, whereas the second one ( $L N E X^{C Z^{*}}$ - Model 2) uses a demand variable constructed as the relation of foreign demand to domestic demand ( $L F D D D)$.

$$
\begin{aligned}
L N E X_{i t}^{C Z}= & \beta_{0}+\beta_{1} L D D_{i t}+\beta_{2} L F D_{i t}+\beta_{3} L R U L C_{i t}+ \\
& \beta_{4} L \operatorname{OPEN}_{i t}+\beta_{5} L L_{P R O_{i t}}+\beta_{6} L I N N O_{i t}+\varepsilon_{i t} \\
L N E X_{i t}^{C Z^{*}}= & \beta_{0}+\beta_{1} L F D D D_{i t}+\beta_{2} L R U L C_{i t}+\beta_{3} L O P E N_{i t}+ \\
& \beta_{4} L \operatorname{LPRO}_{i t}+\beta_{5} L I N N O_{i t}+\varepsilon_{i t}
\end{aligned}
$$

The results for the Pedroni tests and the Kao test are reported in Table 3. All the tests strongly reject the null of no cointegration, for the both models. According to Granger's representation theorem this means that all the above regressions can be presented as an error correction model.

Table 3 | Results for Panel Cointegration Tests

\begin{tabular}{|l|c|c|c|}
\hline & Pedroni panel-t & Pedroni group-t & Kao ADF \\
\hline Model 1 & $-2.462^{* * *}$ & $-3.551^{* * *}$ & $-2.803^{* * *}$ \\
\hline Model 2 & $-5.627^{* * *}$ & $-4.257^{* * *}$ & $-2.920^{* * *}$ \\
\hline
\end{tabular}

Notes: ${ }^{* *}$ significant at the 0.01 level; automatic selection of maximum lags in Eviews; automatic lag length selection based on SIC criterion.

Source: Own calculations. 
In order to estimate ECM we apply a two-step Engle-Granger procedure. In the first step, regressions (4) and (5) are estimated with the DOLS estimator. The number of leads and lags is chosen on the basis of SIC. All the regressions contain individual effects and a deterministic trend. In the second step, DOLS residuals are used to estimate Model (6) and Model (7).

$$
\begin{aligned}
\Delta L N E X_{i t}^{C Z}= & \alpha_{0}+\alpha_{1} \Delta L N E X_{i, t-1}+\sum_{j=0}^{1} \gamma_{1 j} \Delta L D D_{i, t-1}+\sum_{j=0}^{1} \gamma_{2 j} \Delta L F D_{i, t-1}+ \\
& \sum_{j=0}^{1} \gamma_{3 j} \Delta L R U L C_{i, t-1}+\sum_{j=0}^{1} \gamma_{4 j} \Delta L O P E N_{i, t-1}+ \\
& \sum_{j=0}^{1} \gamma_{5 j} \Delta L \operatorname{LPRO}_{i, t-1}+\sum_{j=0}^{1} \gamma_{6 j} \Delta L I N N O_{i, t-1}+\lambda E C M_{t-1}^{L N E X C Z}+\varepsilon_{i t} \\
\Delta L N E X_{i t}^{C Z^{*}}= & \alpha_{0}+\alpha_{1} \Delta L N E X_{i, t-1}+\sum_{j=0}^{1} \gamma_{1 j} \Delta L \operatorname{FDDD}_{i, t-1}+ \\
& \sum_{j=0}^{1} \gamma_{2 j} \Delta L \operatorname{RULC}_{i, t-1}+\sum_{j=0}^{1} \gamma_{3 j} \Delta L \operatorname{OPEN}_{i, t-1}+ \\
& \sum_{j=0}^{1} \gamma_{4 j} \Delta L \operatorname{LPRO}_{i, t-1}+\sum_{j=0}^{1} \gamma_{5 j} \Delta L \operatorname{INNO}_{i, t-1}+\lambda E C M_{t-1}^{L N E X C Z^{*}}+\varepsilon_{i t}
\end{aligned}
$$

where ECM means residuals from DOLS regressions.

The estimation results can be found in Table 4. We are interested in interpreting the long-run calculated elasticities. It can be observed that the high degree of openness of the Czech economy strongly supports the growth of a positive trade balance. This is something we expected for a small economy like the Czech one with exports representing more than $81 \%$ of GDP. However, the key element which determines the generation of a positive trade balance in Czech manufacturing is a decrease in relative unit labour costs. This may indicate the domination of a price/cost competition strategy among Czech manufacturing exporters in the analysed period.

Much smaller than cost factors but still statistically important is the influence of demand factors (i.e. both domestic and foreign demand) and productivity growth on the trade balance of the Czech manufacturing sectors. The growth in domestic demand in the long term (Model 1) influences manufacturing trade surprisingly positively. This is probably related to the large number of specialized exporters of manufactured goods: the intensity of their exports does not rely so heavily on changes in domestic demand, as is the case for non-specialized exporters. Foreign demand evidently helps generate a positive trade balance in the Czech Republic twice as much as domestic demand. This is due to high Czech integration in international supply chains, which offer opportunities for Czech enterprises to enhance efficiency and source inputs globally, investing in specific activities where the location factors are optimal for profit. However, at the same time it leaves the Czech economy strongly exposed to slumps in global trade. 


\begin{tabular}{|c|c|c|c|c|c|c|c|}
\hline \multicolumn{4}{|c|}{ Model 1} & \multicolumn{4}{|c|}{ Model 2} \\
\hline variable & $\begin{array}{l}\text { short-run } \\
\text { elasticities }\end{array}$ & variable & $\begin{array}{l}\text { long-run } \\
\text { elasticities }\end{array}$ & variable & $\begin{array}{l}\text { short-run } \\
\text { elasticities }\end{array}$ & variable & $\begin{array}{l}\text { long-run } \\
\text { elasticities }\end{array}$ \\
\hline$\triangle L D D$ & $\begin{array}{l}-0.005 \\
(0.017)\end{array}$ & $L D D$ & $\begin{array}{l}0.045^{* *} \\
(0.022)\end{array}$ & \multicolumn{2}{|c|}{-} & \multicolumn{2}{|r|}{-} \\
\hline$\Delta L F D 39$ & $\begin{array}{l}-0.061 \\
(0.076)\end{array}$ & LFD39 & $\begin{array}{l}0.089^{*} \\
(0.053)\end{array}$ & $\triangle L F D D D$ & $\begin{array}{l}0.0007 \\
(0.018)\end{array}$ & $L F D D D$ & $\begin{array}{l}0.073^{* * *} \\
(0.020)\end{array}$ \\
\hline$\Delta L R U L C$ & $\begin{array}{l}-0.110^{* * *} \\
(0.024)\end{array}$ & LRULC & $\begin{array}{c}-0.146^{* * *} \\
(0.030)\end{array}$ & $\Delta L R U L C$ & $\begin{array}{c}-0.103^{* * *} \\
(0.026)\end{array}$ & $L R U L C$ & $\begin{array}{c}-0.123^{* * *} \\
(0.016)\end{array}$ \\
\hline$\triangle L O P E N$ & $\begin{array}{l}0.298^{* * *} \\
(0.048)\end{array}$ & LOPEN & $\begin{array}{l}0.198^{* * *} \\
(0.052)\end{array}$ & $\triangle L$ OPEN & $\begin{array}{l}0.284^{* * *} \\
(0.054)\end{array}$ & L OPEN & $\begin{array}{l}0.177^{* * *} \\
(0.025)\end{array}$ \\
\hline$\Delta L I N N O$ & $\begin{array}{l}0.003 \\
(0.012)\end{array}$ & LINNO & $\begin{array}{l}0.044^{* * *} \\
(0.014)\end{array}$ & $\Delta L I N N O$ & $\begin{array}{l}0.0007 \\
(0.013)\end{array}$ & LINNO & $\begin{array}{l}0.021^{* *} \\
(0.008)\end{array}$ \\
\hline$\triangle L L P R O$ & $\begin{array}{l}0.183^{* * *} \\
(0.048)\end{array}$ & L LPRO & $\begin{array}{c}0.009 \\
(0.055)\end{array}$ & $\triangle L L P R O$ & $\begin{array}{l}0.170^{* * *} \\
(0.048)\end{array}$ & L LPRO & $\begin{array}{l}0.089 * * * \\
(0.026)\end{array}$ \\
\hline$\lambda$ & $\begin{array}{c}-0.790 * * * \\
(0.121)\end{array}$ & & - & $\lambda$ & $\begin{array}{c}-0.771^{* * *} \\
(0.221)\end{array}$ & & - \\
\hline $\boldsymbol{R}_{E C M}^{2}$ & 0.517 & & & $R_{E C M}^{2}$ & 0.440 & & \\
\hline
\end{tabular}

Notes: * significant at the 0.1 level, ${ }^{* *}$ significant at the 0.05 level, ${ }^{* * *}$ significant at the 0.01 level, standard errors in parenthesis.

Source: Own calculations.

In addition, growth in productivity only slightly (compared to cost factors) explains the increase in Czech net exports in the analysed period. The role of productivity in net export growth, which is smaller than we expected, shows an unfavourable situation, because boosting productivity is critical for future Czech export growth in the case of limitation of the cost/price advantages. Moreover, the extremely small significance of long-term investment in $\mathrm{R} \& \mathrm{D}(L I N N O)$ in the trade balance of Czech manufacturing confirms a relatively low technological intensity of Czech exported goods.

The speed adjustment parameter, $\lambda$, which determines the pace of adaptation towards the long-term equilibrium level, is negative for both models. This means that deviations from the trend are corrected, and thus the trend can be treated as permanent and is due to fundamental characteristics of the economy. The values of both parameters indicate that the Czech economy has a good capacity to correct these deviations: almost $80 \%$ of the disequilibrium is reduced in one period of time.

It is interesting to go deeper and see how the trade balance, broken down into different manufacturing sub-sectors, reacts to the factors which determine it. To do this, we propose a model which allows individual parameters for each of the 13 sub-sectors to be obtained. Our sample size forces us to abandon DSUR and to focus on the ordinary SUR approach. 
The results of estimating the model are shown in Table 5. In this table, the sectors are sorted in diminishing order, according to each sector's share in total 2011 manufacturing exports.

For all the analysed sub-sectors the speed adjustment parameter $\lambda$ is negative and for the majority of cases except for the DI sector this parameter is significant. This indicates that regardless of the way of approaching the problem, i.e. joint estimation or estimation for individual sub-sectors, Czech manufacturing is capable of reducing short-term imbalances. For 6 of 13 entities a stronger ECM effect is observed. Parameter $\lambda$ is lower than -1 but higher than $-2^{2}$. This suggests that the discrepancies between shocks and the trend are reduced in less than one year. In such cases, equilibrium is achieved by fluctuations of net exports, with the amplitude getting smaller until the final extinction of the shock. This can also indicate that particular sub-sectors are more flexible in absorbing external shocks.

Analysing the results we focus on four main subsectors, manufacturing electrical and optical equipment (DL), transport equipment (DM), machinery and equipment n.e.c. (DK), and basic metals and fabricated metal products (DJ). Together, they represent around $70 \%$ of total Czech manufacturing exports. An increase in trade openness naturally helps the generation of a positive foreign trade balance in the long term, but surprisingly in one of the major sub-sectors (the manufacture of basic metals) an increase in trade openness has a negative influence on the generation of positive net exports. This raises a question about the appropriate degree of openness of the Czech economy, especially its individual sectors.

The results confirm that relative unit labour costs heavily determine the trade balance in Czech manufacturing sub-sectors. These are the second most important (after openness) determinants of net exports in three of the four major subsectors. This indicates a domination of a price strategy by Czech exporters of manufactured goods as a competition tool in foreign markets, a strategy which, given the positive trade balance in manufacturing from 2002, turns out to be effective. Whether this strategy is still valid is an open question.

Relative demand, which plays a less important role in explaining changes in the net exports of 13 manufacturing sub-sectors, is quite important in three crucial subsectors. Two of these are sub-sectors where exports are generated in GV chains: the manufacture of transport equipment and the manufacture of machinery and equipment n.e.c. It is positive that the export/import surplus in these two sub-sectors can be achieved even in a situation when foreign demand is weaker than domestic demand. It is, however, negative that the manufacture of basic metals and fabricated metal products has a strong dependence on the economic situation in foreign markets, i.e. in the long-term positive net exports are only generated when the relative demand increases.

Labour productivity and investment in R\&D are not essential in explaining changes in the trade balance of the major sectors. Productivity growth only positively and significantly influences the generation of positive net exports in the manufacture of transport equipment, and investment in $\mathrm{R} \& \mathrm{D}$ only plays a key role in explaining changes in net exports in the manufacture of machinery and equipment. Insufficient use of the productivity gap between the Czech Republic and the EU15 economies and the low innovation level of the goods exported are the most import weakness of the Czech trade balance, but at the same time they represent the most important opportunities for its growth in the future.

2 When considering the ARDL (1,1) model, $y_{i t}=\alpha_{0}+\alpha_{1} y_{i, t-1}+\beta_{0} x_{i t}+\beta_{1} x_{i, t-1}+\varepsilon_{i t}$, an assumption about the parameter $\alpha_{1}$ needs to be made. We assume that $\left|\alpha_{1}\right|<1$. The ARDL $(1,1)$ model can be presented as an ECM regression. In this model the speed adjustment parameter, $\lambda=\alpha_{1}-1$. Therefore, $\lambda \in(-2,0)$. 
Table 5 | ECM Results for Net Exports Disaggregated by Sub-Sectors

\begin{tabular}{|c|c|c|c|c|c|c|c|c|c|c|c|c|c|}
\hline & \multicolumn{5}{|c|}{ short-run elasticities } & \multicolumn{5}{|c|}{ long-run elasticities } & \multirow[b]{2}{*}{$\lambda$} & \multirow[b]{2}{*}{$R_{E C M}^{2}$} & \multirow[b]{2}{*}{ share } \\
\hline $\begin{array}{l}\text { sec- } \\
\text { tor }\end{array}$ & $\triangle L F D D D$ & $\Delta L R U L C$ & $\triangle L O P E N$ & $\triangle L L P R O$ & $\Delta L I N N O$ & $L F D D D$ & $L R U L C$ & LOPEN & LLPRO & LINNO & & & \\
\hline$D L$ & $\begin{array}{l}0.044^{* *} \\
(0.021)\end{array}$ & $\begin{array}{l}-0.050 \\
(0.082)\end{array}$ & $\begin{array}{c}0.561^{* * *} \\
(0.061)\end{array}$ & $\begin{array}{c}0.334^{* * *} \\
(0.083)\end{array}$ & $\begin{array}{c}-0.089^{* * * *} \\
(0.031)\end{array}$ & $\begin{array}{l}-0.058 \\
(0.035)\end{array}$ & $\begin{array}{l}-0.040 \\
(0.157)\end{array}$ & $\begin{array}{c}0.705^{* * *} \\
(0.055)\end{array}$ & $\begin{array}{c}0.019 \\
(0.072)\end{array}$ & $\begin{array}{l}-0.073 \\
(0.057)\end{array}$ & $\begin{array}{c}-0.439^{* * *} \\
(0.077)\end{array}$ & 0.81 & 27.65 \\
\hline$D M$ & $\begin{array}{l}0.005 \\
(0.054)\end{array}$ & $\begin{array}{c}-0.262^{* * *} \\
(0.037)\end{array}$ & $\begin{array}{c}0.595^{* * *} \\
(0.062)\end{array}$ & $\begin{array}{c}-0.0003 \\
(0.051)\end{array}$ & $\begin{array}{l}0.067^{*} \\
(0.040)\end{array}$ & $\begin{array}{c}-0.137^{* * *} \\
(0.036)\end{array}$ & $\begin{array}{c}-0.250^{* * *} \\
(0.042)\end{array}$ & $\begin{array}{c}0.503^{* * *} \\
(0.058)\end{array}$ & $\begin{array}{c}0.070^{* * *} \\
(0.026)\end{array}$ & $\begin{array}{c}0.154^{* * *} \\
(0.041)\end{array}$ & $\begin{array}{c}-0.703^{* * *} \\
(0.169)\end{array}$ & 0.81 & 20.33 \\
\hline$D K$ & $\begin{array}{c}-0.143^{* * *} \\
(0.033)\end{array}$ & $\begin{array}{c}-0.406^{* * *} \\
(0.109)\end{array}$ & $\begin{array}{c}0.749^{* * *} \\
(0.128)\end{array}$ & $\begin{array}{l}-0.030 \\
(0.129)\end{array}$ & $\begin{array}{c}0.033 \\
(0.048)\end{array}$ & $\begin{array}{c}-0.143^{* * *} \\
(0.031)\end{array}$ & $\begin{array}{l}-0.156^{*} \\
(0.090)\end{array}$ & $\begin{array}{l}0.728^{* * *} \\
(0.098)\end{array}$ & $\begin{array}{l}0.146^{* *} \\
(0.072)\end{array}$ & $\begin{array}{l}0.040 \\
(0.050)\end{array}$ & $\begin{array}{c}-1.061^{* * *} \\
(0.169)\end{array}$ & 0.69 & 11.77 \\
\hline DJ & $\begin{array}{l}0.161^{* * *} \\
(0.128)\end{array}$ & $\begin{array}{c}-0.146^{* * *} \\
(0.041)\end{array}$ & $\begin{array}{c}-0.341^{* * *} \\
(0.067)\end{array}$ & $\begin{array}{l}-0.089 \\
(0.063)\end{array}$ & $\begin{array}{c}0.160^{* * *} \\
(0.037)\end{array}$ & $\begin{array}{c}0.108^{* * *} \\
(0.038)\end{array}$ & $\begin{array}{c}-0.169 * * * \\
(0.062)\end{array}$ & $\begin{array}{c}-0.243^{* * *} \\
(0.056)\end{array}$ & $\begin{array}{l}-0.024 \\
(0.080)\end{array}$ & $\begin{array}{l}0.075 \\
(0.049)\end{array}$ & $\begin{array}{c}-1.220^{* * *} \\
(0.169)\end{array}$ & 0.73 & 10.98 \\
\hline$D G$ & $\begin{array}{c}-0.073^{* * *} \\
(0.016)\end{array}$ & $\begin{array}{c}-0.214^{* *} \\
(0.097)\end{array}$ & $\begin{array}{c}0.353^{* * *} \\
(0.108)\end{array}$ & $\begin{array}{l}-0.153 \\
(0.095)\end{array}$ & $\begin{array}{l}0.145^{*} \\
(0.075)\end{array}$ & $\begin{array}{l}-0.050^{*} \\
(0.027)\end{array}$ & $\begin{array}{c}-0.373^{* * *} \\
(0.056)\end{array}$ & $\begin{array}{c}0.336^{* * *} \\
(0.109)\end{array}$ & $\begin{array}{l}-0.145 \\
(0.107)\end{array}$ & $\begin{array}{c}0.330^{* * *} \\
(0.103)\end{array}$ & $\begin{array}{c}-0.753^{* * *} \\
(0.158)\end{array}$ & 0.58 & 6.31 \\
\hline$D H$ & $\begin{array}{l}0.032^{* *} \\
(0.015)\end{array}$ & $\begin{array}{c}-0212^{* * *} \\
(0.048)\end{array}$ & $\begin{array}{c}0.200^{* * *} \\
(0.066)\end{array}$ & $\begin{array}{c}0.188^{* * *} \\
(0.062)\end{array}$ & $\begin{array}{c}-0.00007 \\
(0.012)\end{array}$ & $\begin{array}{l}-0.020 \\
(0.023)\end{array}$ & $\begin{array}{c}-0.187^{* * * *} \\
(0.050)\end{array}$ & $\begin{array}{l}0.181^{* * *} \\
(0.064)\end{array}$ & $\begin{array}{l}0.211^{* * *} \\
(0.030)\end{array}$ & $\begin{array}{l}0.018 \\
(0.016)\end{array}$ & $\begin{array}{c}-1.066^{* * *} \\
(0.118)\end{array}$ & 0.73 & 5.11 \\
\hline$D N$ & $\begin{array}{c}-0.037^{*} \\
(0.021)\end{array}$ & $\begin{array}{l}-0.018 \\
(0.038)\end{array}$ & $\begin{array}{l}-0.110^{*} \\
(0.060)\end{array}$ & $\begin{array}{l}-0.052 \\
(0.064)\end{array}$ & $\begin{array}{c}-0.106^{* * *} \\
(0.009)\end{array}$ & $\begin{array}{l}-0.027 \\
(0.036)\end{array}$ & $\begin{array}{c}-0.140^{* *} \\
(0.064)\end{array}$ & $\begin{array}{c}0.249 * * * \\
(0.046)\end{array}$ & $\begin{array}{l}-0.036 \\
(0.036)\end{array}$ & $\begin{array}{c}-0.100^{* * *} \\
(0.017)\end{array}$ & $\begin{array}{c}-0.916^{* * *} \\
(0.082)\end{array}$ & 0.88 & 3.81 \\
\hline $\begin{array}{l}D B \\
D C\end{array}$ & $\begin{array}{l}-0.028 \\
(0.035)\end{array}$ & $\begin{array}{c}-0.435^{* * *} \\
(0.103)\end{array}$ & $\begin{array}{l}0.055 \\
(0.175)\end{array}$ & $\begin{array}{l}0.208^{*} \\
(0.122)\end{array}$ & $\begin{array}{c}0.158^{* * *} \\
(0.024)\end{array}$ & $\begin{array}{l}0.071^{*} \\
(0.040)\end{array}$ & $\begin{array}{l}-0.143 \\
(0.093)\end{array}$ & $\begin{array}{c}-0.664^{* * *} \\
(0.104)\end{array}$ & $\begin{array}{c}-0.245^{* * *} \\
(0.041)\end{array}$ & $\begin{array}{c}0.175^{* * * *} \\
(0.035)\end{array}$ & $\begin{array}{c}-0.900^{* * *} \\
(0.142)\end{array}$ & 0.83 & 3.39 \\
\hline$D A$ & $\begin{array}{c}-0.178^{* *} \\
(0.069)\end{array}$ & $\begin{array}{c}-0.152^{* * *} \\
(0.053)\end{array}$ & $\begin{array}{c}0.116 \\
(0.089)\end{array}$ & $\begin{array}{l}-0.118 \\
(0.110)\end{array}$ & $\begin{array}{c}0.076^{* * *} \\
(0.022)\end{array}$ & $\begin{array}{c}-0.219^{* * *} \\
(0.074)\end{array}$ & $\begin{array}{l}-0.082 \\
(0.052)\end{array}$ & $\begin{array}{c}0.218^{* * *} \\
(0.075)\end{array}$ & $\begin{array}{c}-0.258^{* * *} \\
(0.042)\end{array}$ & $\begin{array}{l}0.031 \\
(0.024)\end{array}$ & $\begin{array}{c}-1.323^{* * *} \\
(0.218)\end{array}$ & 0.82 & 3.15 \\
\hline$D E$ & $\begin{array}{c}0.148^{* * *} \\
(0.050)\end{array}$ & $\begin{array}{l}0.085 \\
(0.052)\end{array}$ & $\begin{array}{l}0.149 \\
(0.093)\end{array}$ & $\begin{array}{l}-0.024 \\
(0.072)\end{array}$ & $\begin{array}{c}0.023^{* * *} \\
(0.008)\end{array}$ & $\begin{array}{c}0.208^{* * *} \\
(0.042)\end{array}$ & $\begin{array}{l}0.130^{* * * *} \\
(0.045)\end{array}$ & $\begin{array}{l}0.210^{* * *} \\
(0.054)\end{array}$ & $\begin{array}{c}0.216^{* * *} \\
(0.033)\end{array}$ & $\begin{array}{c}0.029 * * * \\
(0.006)\end{array}$ & $\begin{array}{c}-1.111^{* * *} \\
(0.176)\end{array}$ & 0.70 & 2.99 \\
\hline DI & $\begin{array}{l}-0.007 \\
(0.022)\end{array}$ & $\begin{array}{l}-0.124 \\
(0.108)\end{array}$ & $\begin{array}{c}0.574^{* * *} \\
(0.129)\end{array}$ & $\begin{array}{l}0.070 \\
(0.122)\end{array}$ & $\begin{array}{l}-0.036 \\
(0.028)\end{array}$ & $\begin{array}{l}0.050^{*} \\
(0.028)\end{array}$ & $\begin{array}{c}0.015 \\
(0.107)\end{array}$ & $\begin{array}{c}0.486^{* * * *} \\
(0.138)\end{array}$ & $\begin{array}{l}-0.075 \\
(0.060)\end{array}$ & $\begin{array}{c}-0.095^{* * * *} \\
(0.033)\end{array}$ & $\begin{array}{l}-0.280 \\
(0.190)\end{array}$ & 0.41 & 2.10 \\
\hline$D F$ & $\begin{array}{c}-0.789 * * * \\
(0.073)\end{array}$ & $\begin{array}{c}-0.197^{* * *} \\
(0.016)\end{array}$ & $\begin{array}{c}0.245^{* * *} \\
(0.061)\end{array}$ & $\begin{array}{c}0.200^{* * *} \\
(0.050)\end{array}$ & $\begin{array}{c}0.195^{* * *} \\
(0.043)\end{array}$ & $\begin{array}{c}-0.774^{* * *} \\
(0.127)\end{array}$ & $\begin{array}{c}-0.190^{* * *} \\
(0.024)\end{array}$ & $\begin{array}{l}0.051^{*} \\
(0.031)\end{array}$ & $\begin{array}{c}0.030 \\
(0.045)\end{array}$ & $\begin{array}{l}0.118^{* *} \\
(0.057)\end{array}$ & $\begin{array}{c}-1.194^{* * *} \\
(0.146)\end{array}$ & 0.92 & 1.27 \\
\hline$D D$ & $\begin{array}{l}-0.009 \\
(0.013)\end{array}$ & $\begin{array}{c}-0.113^{* *} \\
(0.047)\end{array}$ & $\begin{array}{l}0.422^{* * *} \\
(0.098)\end{array}$ & $\begin{array}{l}0.197^{* *} \\
(0.083)\end{array}$ & $\begin{array}{c}-0.031^{* * * *} \\
(0.010)\end{array}$ & $\begin{array}{l}-0.063 \\
(0.046)\end{array}$ & $\begin{array}{l}-0.067 \\
(0.120)\end{array}$ & $\begin{array}{c}0.188 \\
(0.230)\end{array}$ & $\begin{array}{l}-0.187 \\
(0.117)\end{array}$ & $\begin{array}{c}-0.0005 \\
(0.036)\end{array}$ & $\begin{array}{c}-0.433^{* * *} \\
(0.069)\end{array}$ & 0.77 & 1.13 \\
\hline
\end{tabular}

Notes: ${ }^{*}$ significant at the 0.1 level, ${ }^{* *}$ significant at the 0.05 level, ${ }^{* * *}$ significant at the 0.01 level, standard errors in parenthesis

Source: Own calculation. 


\section{Summary of the Findings and Conclusions}

The Czech Republic is a small open economy, for which exports represent a major source of growth and positive net exports is a sign of a high level of international competitiveness. Therefore, knowledge about the main determinants of net exports, especially at the level of individual sectors, seems to be crucial for creating an appropriate export-led growth strategy.

The aim of this study has been to fill the gap in the empirical literature on the determinants of Czech net exports. This paper has added to the few existing empirical works by specifying the net export performance equation not only as a function of foreign demand and price or cost factors, as is done traditionally, but also of the size of domestic demand, the level of innovation intensity, the level of openness to foreign markets and labour productivity. Our new approach is also based on employing an error correction model to disaggregated sectoral manufacturing data. It has additionally allowed the speed of adjustment to long-run equilibrium to be estimated and the ability of the Czech economy to correct deviations from equilibrium to be assessed.

The results obtained show that the Czech trade surplus grew strongly due to a favourable cost effect, i.e. decreasing relative unit costs promotes net Czech export growth. In recent years the Czech Republic has been regarded as a traditionally low-cost manufacturing country, but nowadays it appears to be under pressure as a result of a combination of factors that have significantly eroded the cost advantage during the last decade. The Czech export strategy for future years can no longer be based on low production costs, but on increasing productivity (productivity should increase more dynamically than wages) or high R\&D intensity in exported products. We have found that that both productivity and innovation were for a long time statistically important only in one out of four main Czech sub-sectors. We strongly recommend the promotion of Czech exports of products with a high R\&D intensity and labour productivity growth as the main sources of Czech positive net exports in the future, in particular because these two variables are often tied with each other, i.e. increasing innovation has a positive and clear impact on productivity growth.

The results confirm that positive Czech net exports are dependent on foreign demand, probably relying on the activity of multinational corporations. This situation is unfavourable, with Czech exporters being tied to imports of parts and components, and their products being re-exported. Such exports of manufactured goods, especially in main export sectors, such as the manufacturing of transport equipment, electronic equipment and machinery, are sensitive to foreign, mainly EU15, demand, and do not allow a high gross value to be generated in GV chains. The participation of the Czech Republic in GVCs through exporting is mainly driven by foreign intermediation, and backward participation in the main export sectors is extremely high. We recommend some geographical export reorientation, i.e. identifying new final international markets with a higher potential for the generation of added value. It is highly desirable that the existing specializations of Czech exporters be refocussed by developing the skills associated with acquiring new markets (strategic management, marketing innovation management, legal trade know-how, and direct investment abroad). The Czech Republic should also attract FDI mainly in the areas of R\&D and services, i.e. investments with high added value requiring less invested capital.

We hope that the results of these estimations will contribute to discussion of the instruments which can help enhance the competitiveness of particular sub-sectors of manufacturing, especially given that positive trade balance generation in manufacturing is a key priority 
in the Czech strategy for export growth for 2012-2020. Once the data is available, further estimation of models for a longer time series would be desirable. If different databases make the data available, new explanatory variables such as the value of FDI could be taken into account in the model.

\section{References}

Anderton, B. (1999). UK Trade Performance and the Role of Product Quality, Innovation and Hysteresis: Some Preliminary Result. Scottish Journal of Political Economy, 46(5), 570-595 http://dx.doi.org/10.1111/1467-9485.00148

Bahmani-Oskooee, M. (1985). Devaluation and the J-curve: Some Evidence from LDCs. The Review of Economics and Statistics, 67(3), 500-504, http://dx.doi.org/10.2307/1925980

(1991). Is There a Long-Run Relation between the Trade Balance and the Real Effective Rate of LDCs. Economics Letters, 36(4), 403-407, http://dx.doi.org/10.1016/01651765(91)90206-Z

Breitung, J. (2000). The Local Power of Some Unit Root Tests for Panel Data, in Baltagi, B.,ed., Nonstationary Panels, Panel Cointegration, and Dynamic Panels Advances in Econometrics, 15, Amsterdam: JAI, pp. 161-178.

Bustos, P. (2011). Trade Liberalization, Exports, and Technology Upgrading: Evidence on the Impact of MERCOSUR on Argentinian Firms. American Economic Review, 101(1), 304-340, http://dx.doi.org/10.1257/aer.101.1.304

Cameron, G., Proudman, J., Redding, S. (2005). Technological Convergence, R\&D, Trade and Productivity Growth. European Economic Review, 49(3), 775-807, http://dx.doi.org/10.1016/S0014-2921(03)00070-9

Cieślik, A., Michałek, J., Michałek, A. (2012). Determinanty działalności eksportowej polskich przedsiębiorstw. (Determinants of Export Activities of Polish Enterprises), Gospodarka Narodowa, 7-8, 67-84. Available at: http://gospodarkanarodowa.sgh.waw.pl/p/gospodarka_narodowa_2012_07-08_04.pdf

De Loecker, J. (2007). Do Exports Generate Higher Productivity? Evidence from Slovenia. Journal of International Economics, 73(1), 69-98, http://dx.doi.org/10.1016/j.jinteco.2007.03.003

Deardorff, A. V. (1980). The General Validity of the Law of Comparative Advantage. Journal of Political Economy, 88(5), 941-957, http://dx.doi.org/10.1086/260915

Dixit, A. K., Stiglitz, J. E. (1977). Monopolistic Competition and Optimum Product Diversity. American Economic Review, 67(3), 297-308. Available at: https://assets.aeaweb.org/assets/ production/journals/aer/top20/67.3.297-308.pdf

Dollar, D. (1986). Technological Innovation, Capital Mobility and the Product Cycle in North-South Trade. The American Economic Review, 76(1), 177-190. Available at: http://www.jstor.org/ stable/1804135

Engle, R. F., Granger, C. W. J. (1987). Co-integration and Error Correction: Representation, Estimation, and Testing. Econometrica, 55(2), 251-276, http://dx.doi.org/10.2307/1913236

Faini, R. (1994). Export Supply, Capacity and Relative Prices. Journal of Development Economics, 45(1), 81-100, http://dx.doi.org/10.1016/0304-3878(94)90060-4

Greenhalgh, Ch. A., Taylor, P., Wilson, R. (1994). Innovation and Export Volumes and Prices A Disaggregated Study. Oxford Economic Papers, 16(1), 102-135.

Grossman, G. M., Helpman, E. (1991). Innovation and Growth in the Global Economy. Cambridge, USA and London, UK: MIT press. ISBN: 9780262071369.

Im, K. S., Pesaran, M. H., Shin, Y. (2003). Testing for Unit Roots in Heterogeneous Panels. Journal of Econometrics, 155(1), 53-74, http://dx.doi.org/10.1016/S0304-4076(03)00092-7 
Kao, Ch. (1999). Spurious Regression and Residual-Based Tests for Cointegration in Panel Data. Journal of Econometrics, 90(1), 1-44, http://dx.doi.org/10.1016/S0304-4076(98)00023-2

Chiang, M. (2000). On the Estimation and Inference of a Cointegrated Regression in Panel Data. Advances in Econometrics, 15, 179-222, http://dx.doi.org/10.1016/s07319053(00)15007-8

Krugman, P. (1979). A Model of Innovation, Technology Transfer and the World Distribution of Income. Journal of Political Economy, 87(2), 253-266, http://dx.doi.org/10.1086/260755

Lewney, R. (2011). Study on the Cost Competitiveness of European Industry in the Globalization Era-Empirical Evidence on the Basis of Relative Unit Labour Cost at Sectoral Level. Nederland: Ecorys.

Mark, N. C., Ogaki, M., Sul, D. (2005). Dynamic Seemingly Unrelated Cointegrating Regressions. Review of Economic Studies, 72(3), 797-820, http://dx.doi.org/10.1111/j.1467937X.2005.00352.x

Melitz, M. J. (2003). The Impact of Trade on Intra-Industry Reallocations and Aggregate Industry Productivity. Econometrica, 71(6), 1695-1725, http://dx.doi.org/10.1111/1468-0262.00467 Ottaviano, G. I. P. (2008). Market Size, Trade and Productivity. Review of Economic Studies, 75(1), 295-316,http://dx.doi.org/10.1111/j.1467-937X.2007.00463.x

Örsal, D. D. K. (2008). Comparison of Panel Cointegration Tests. Economics Bulletin, 3(6), 1-20.

Pedroni, P. (1999). Critical Values for Cointegration Tests in Heterogeneous Panels with Multiple Regressors. Oxford Bulletin of Economics and Statistics, 61(s1), 653-670, http://dx.doi.org/10.1111/1468-0084.0610s1653

Pesaran, M. H. (2003). A Simple Panel Unit Root Test in the Presence of Cross Section Dependence. University of Cambridge, Cambridge Working Papers in Economics No. 0346.

Porter, M. E. (1990). The Competitive Advantage of Nation. New York: Macmillan Press.

Posner, M.V. (1961). International Trade and Technical Change. Oxford Economic Paper, 13(3), 323-341. Available at: http://oep.oxfordjournals.org/content/13/3/323.full.pdf+html

Rivera-Batiz, L. A., Romer, P. M. (1991). International Trade with Endogenous Technological Change. European Economic Review, 35(4), 971-1001, http://dx.doi.org/10.1016/00142921(91)90048-N

Robinson, J. (1937). The Foreign Exchange, in Robinson, J., ed., Essays in the Theory of Employment. London: Macmillan, pp. 183-209.

Sharma, K. (2003). Factors Determining India's Export Performance. Journal of Asia Economics, 14(3), 435-446, http://dx.doi.org/10.1016/S1049-0078(03)00036-8

Soete, L. L. G. (1981). A General Test of Technological Gap Trade Theory. Weltwirtschaftiches Archiv, 117(4), 638-660, http://dx.doi.org/10.1007/BF02708115

Sun, H., Hone, P., Doucouliago, H. (1999). Economic Openness and Technical Efficiency: A Case Study of Chinese Manufacturing Industries. Economics of Transition, 7(3), 615-636, http://dx.doi.org/10.1111/1468-0351.00028

Timmer, M. P., Dietzenbacher, E., Los, B., Stehrer, R., de Vries, G. J. (2015).

An Illustrated User Guide to the World Input-Output Database: The Case of Global

Automotive Production. Review of International Economics, 23(3), 575-605, http://dx.doi.org/10.1111/roie.12178

Thirlwall, A. P. (1988). Balance of Payment Theory and UK Experience. London: Macmillan.

Turner, A. G., Golub, S. S. (1997). Towards a System of Multilateral Unit Labor Cost-Based Competitiveness Indicators for Advanced, Developing and Transition Countries. IMF Working Paper No. 97/151. 
Turner, P., Van 't dack, J. (1993). Measuring International Price and Cost Competitiveness. Bank for International Settlements, Basle, BIS Economic Papers No. 39.

Vernon, R. (1966). International Investment and International Trade in The Product Cycle. The Quarterly Journal of Economics, 80(2), 190-207, http://dx.doi.org/10.2307/1880689

Wagner, J. (2008). Export Entry, Export Exit and Productivity in German Manufacturing Industries. International Journal of the Economics of Business, 15(2), 169-180, http://dx.doi.org/10.1080/13571510802134270

Wagner, M., Hlouskova, J. (2010). The Performance of Panel Cointegration Methods: Results from a Large Scale Simulation Study. Econometric Reviews, 29(2), 182-233, http://dx.doi.org/10.1080/07474930903382182

Wakelin, K. (1998). The Role of Innovation in Bilateral OECD Trade Performance. Applied Economics, 30(10), 1335-1346, http://dx.doi.org/10.1080/000368498324959 